\title{
PENGETAHUAN ORANG TUA TENTANG PEMBERIAN OBAT ORAL CAIR PADA ANAK DI RUANG KANAK - KANAK RUMAH SAKIT UMUM DAERAH JAYAPURA
}

\author{
Roy M. Wangguway ${ }^{1}$, Nurhidayah $\mathrm{Amir}^{2}$, Dewi Suhardi ${ }^{3}$ \\ ${ }^{1)}$ Rumah Sakit Umum Daerah Jayapura - Papua \\ ${ }^{2)}$ Prodi S1 Keperawatan Stikes Jayapura \\ Email: nurhidayahamir07@gmail.com
}

\begin{abstract}
ABSTRAK
Latar Belakang: Peran orang tua pada anak yang sakit dengan menjaga kesehatan membutuhkan pengetahuan dalam pemberian obat. Pemberian obat yang salah meliputi waktu dan cara pemberian mengakibatkan kelebihan atau kekurangan dosis obat yang berdampak pada kesembuhan serta gangguan kesehatan lainnya. Tujuan penelitian: Diketahui pengetahuan orang tua tentang pemberian obat oral cair pada anak di Ruang Kanak - Kanak Rumah Sakit Umum Daerah Jayapura. Metode penelitian: Deskriptif kuantitatif di Ruang Anak-Anak RSUD Jayapura denganpopulasi pada orang tua pasien anak yang dilaksanakan pada bulan Agustus - Oktober 2019. Data diperoleh menggunakan kuesioner dan dianalisis menggunakan chi square. Hasil penelitian: Pengetahuan orang tua tentang pemberian obat oral cair pada anak di Ruang Kanak - Kanak RSUD Jayapura dalam kategori pengetahuan baik sebanyak 21 orang $(53,8 \%)$, pengetahuan cukup sebanyak 13 orang $(33,3 \%)$ dan pengetahuan kurang sebanyak 5 orang $(12,8 \%)$. Simpulan: Dapat disimpulkan bahwa pengetauan orang tua tentang pemberian obat oral cair tertinggi yaitu pengetahuan baik.
\end{abstract}

Kata kunci : Pengetahuan, Obat Oral Cair, Orang Tua

\section{ABSTRACT}

Background: The role of parents in sick children by maintaining health requires knowledge in providing medicine. Wrong administration of drugs including the time and method of submitting excess or underdosage of drugs that have an impact on recovery and other health problems. The purpose of research: to study the knowledge of parents about giving liquid medicine to children in the Kindergarten Room of Jayapura Regional General Hospital. Methods of research : Quantitative descriptive in Children Room Jayapura Regional Hospital with a population of parents conducted for 1 month on 4 September to 4 October 2019. Data were obtained using a questionnaire and analyzed using chi square. Results of research: Parental knowledge about giving liquid medicine to children in the Children Room of Jayapura Regional Hospital in the category of good knowledge as many as 21 people (53.8\%), enough knowledge as many as 13 people (33.3\%) and less knowledge as many as 5 people (12.8\%). Conclusion: The conclussin is knowledge of parent about liquid medicine oral is higher good knowledge.

Keyword : Knowledge, Oral Drugs Liquid Medicine, Parent

\section{PENDAHULUAN}

Obat adalah alat utama terapi yang digunakan dokter untuk mengobati pasien yang memiliki masalah kesehatan, walaupun obat menguntungkan pasien, obat juga menimbulkan efek samping yang serius dan berisiko menimbulkan efek yang berbahaya (Wahyuni, 2015).
World Health Organization (WHO) tahun 2017 melaporkan bahwa sebanyak 40\% masyarakat di dunia menyimpan obat untuk swamedikasi. penggunaan obat antibiotik, anti histamine, analgesik dan multivitamin.

Data dari Riset Kesehatan Dasar tahun 2018 penggunaan obat di rumah tangga masyarakat di Indonesia 383.976 rumah tangga di Indonesia, sebanyak 202.878 rumah 
tangga $(36,1 \%)$ menyimpan obat untuk swamedikasi. Rerata sediaan obat yang disimpan hampir 3 macam. Dari 43,3\% rumah tangga yang menyimpan obat, proporsi rumah tangga yang menyimpan obat keras sebanyak $37,3 \%$ dan antibiotika $24,7 \%$. Obat dengan resep dokter diperoleh saat pasien menjalani rawat inap dan rawat jalan. Penduduk Indonesia yang melakukan rawat inap sebanyak 4,1\% (Kemenkes RI, 2018).

Peran orang tua pada keluarga terutama pada anak dengan menjaga kesehatan anggota keluarganya (Harmoko, 2012). Panagakou dkk (2012) di Yunani melaporkan bahwa pengetahuan yang kurang memadai, sikap yang kurang tepat dan praktik yang salah tentang pemberian obat pada anak secara signifikan berhubungan dengan beberapa faktor, yaitu status orang tua (ayah), pendidikan yang rendah, status imigran, single parent, pendapatan yang rendah, jumlah anak $<2$ atau $>3$, tinggal di pulau, dan tidak memiliki pengalaman. Penelitian lain oleh Quizhpe dkk (2013) di Ekuador menunjukkan tingkat kepatuhan pengobatan, pengetahuan tentang resiko penggunaan obat dan pengetahuan tentang resistensi antibiotik pada ibu berusia dewasa lebih baik dibandingkan ibu berusia remaja ( $<19$ tahun). Penelitian yang dilakukan oleh Fithriya (2014) di Kabupaten Malang mengungkapkan bahwa pengetahuan berhubungan dengan pemberian obat pada anak.

Data yang diperoleh jumlah anak yang dirawat di Ruang Kanak-kanak RSUD Jayapura tahun 2017 sebanyak 1.932 anak dan tahun 2018 sebanyak 1.863 anak (Data Rekam Medik RSUD Jayapura, 2018). Jumlah anak yang dirawat pada bulan Januari 2019 sebanyak 63 anak.

Berdasarkan hasil wawancara pada 3 orang perawat di Ruang Kanak-kanak mengungkapkan bahwa beberapa orang tua dalam memberikan anaknya obat oral cair dalam bentuk syrup menggunakan sendok makan tanpa menggunakan sendok takar khusus obat yang tersedia dalam kemasan obat. Ketika disampaikan kepada orang tua, mereka mengatakan ukurannnya sama dengan sendok takar dan tidak berpengaruh terhadap kesehatan.

Berdasarkan permasalahan tersebut, maka peneliti tertarik untuk melakukan suatu penelitian dengan judul "Pengetahuan Orang Tua tentang Pemberian Obat Oral Cair pada anak di Ruang Kanak-kanak Rumah Sakit Umum Daerah Jayapura”.

\section{METODE PENELITIAN}

Jenis penelitian ini adalah deskriptif kuantitatif. Populasi adalah jumlah anak yang dirawat pada Bulan Januari 2019 sebanyak 63 anak dan sampel yang diambil berdasarkan purposive sampling sebanyak 39 orang (ibu) di Ruang Anak-Anak RSUD Jayapura yang dilaksanakan pada bulan Agustus sampai dengan Oktober 2019.

Pengambilan data diperoleh dengan menggunakan kuesioner. Data yang telah diperoleh kemudian dianalisis menggunakan chi square.

\section{HASIL PENELITIAN}

\section{Karakteristik Responden}

Tabel 1 Distribusi Frekuensi Karakteristik Responden di Ruang Kanak - Kanak

\begin{tabular}{|c|c|c|c|}
\hline No & $\begin{array}{l}\text { Karakteristik } \\
\text { Responden }\end{array}$ & $\mathrm{n}$ & $\%$ \\
\hline \multirow[t]{4}{*}{1} & Jenis Kelamin & & \\
\hline & Laki-Laki & 4 & 10,3 \\
\hline & Perempuan & 35 & 89,7 \\
\hline & Total & 39 & 100 \\
\hline \multirow[t]{5}{*}{2} & Umur & & \\
\hline & $<25$ Tahun & 1 & 2,6 \\
\hline & 26-35 Tahun & 16 & 41 \\
\hline & $>35$ Tahun & 22 & 56,4 \\
\hline & Total & 39 & 100 \\
\hline \multirow[t]{6}{*}{3} & Pendidikan & & \\
\hline & SD & 1 & 2,6 \\
\hline & SMP & 5 & 12,8 \\
\hline & SMA & 28 & 71,8 \\
\hline & Perguruan Tinggi & 5 & 12,8 \\
\hline & Total & 39 & 100 \\
\hline \multirow[t]{7}{*}{4} & Pekerjaan & & \\
\hline & IRT/Tidak Kerja & 26 & 66,6 \\
\hline & PNS & 7 & 17,9 \\
\hline & TNI/Polri & 1 & 2,6 \\
\hline & BUMN/BUMD & 1 & 2,6 \\
\hline & Swasta & 4 & 10,3 \\
\hline & Total & 39 & 100 \\
\hline \multirow[t]{4}{*}{5} & Pengalaman & & \\
\hline & $\mathrm{Ya}$ & 38 & 97,4 \\
\hline & Tidak & 1 & 2,6 \\
\hline & Total & 39 & 100 \\
\hline \multirow[t]{4}{*}{6} & Informasi & & \\
\hline & $\mathrm{Ya}$ & 33 & 84,6 \\
\hline & Tidak & 6 & 15,4 \\
\hline & Total & 39 & 100 \\
\hline
\end{tabular}

Tabel 1 menunjukan dari 39 responden orang tua didominasi oleh ibu atau perempuan 
sebanyak 35 orang $(89,7 \%)$. Adapun umur orang yang diklasifikasikan menurut Depkes RI (2009) sebagian besar berumur dewasa madya, yaitu umur 26-35 tahun sebanyak 16 orang $(41 \%)$. Tingkat pendidikan orang tua sebagian besar responden berpendidikan SMA sebanyak 28 orang $(71,8 \%)$ dan pekerjaan orang tua didominiasi tidak bekerja sebanyak 26 orang $(66,6 \%)$. Adapun pernyataan reponden tentang pengalamannya dalam memberikan obat cair oral sebanyak 38 orang $(97,4 \%)$ dan sebanyak 33 orang $(84,6 \%)$ mendapatkan informasi tentang pemberian obat cair oral pada anak.

\section{Pengetahuan tentang Pemberian Obat Oral Cair Pada anak}

Tabel 2 Distribusi Pengetahuan tentang Pemberian Obat Oral Cair Pada anak di Ruang Kanak - Kanak RSUD Jayapura

\begin{tabular}{cccc}
\hline No & Pengetahuan & $\mathrm{n}$ & $\%$ \\
\hline 1 & Baik & 21 & 53,8 \\
2 & Cukup & 13 & 33,4 \\
3 & Kurang & 5 & 12,8 \\
\hline & Total & 39 & 100 \\
\hline
\end{tabular}

Tabel 2 menunjukkan dari 39 responden di Ruang Kanak - Kanak RSUD Jayapura dalam kategori pengetahuan baik sebanyak 21 orang $(53,8 \%)$, pengetahuan cukup sebanyak 13 orang $(33,4 \%)$ dan pengetahuan kurang sebanyak 5 orang $(12,8 \%)$.

\section{PEMBAHASAN}

\section{Karakteristik Responden}

Hasil penelitian diperoleh dari 39 responden orang tua didominasi oleh ibu atau perempuan sebanyak 35 orang $(89,7 \%)$. Hal ini menunjukkan ibu berperan sangat penting dalam perawatan anak. Wanita atau ibu adalah pengurus generasi keluarga dan bangsa sehingga keberadaan wanita yang sehat jasmani dan rohani serta sosial sangat diperlukan yang adalah makhluk bio-psikososial-cultural dan spiritual yang utuh dan unik, mempunyai kebutuhan dasar yang bermacam-macam sesuai dengan tingkat perkembangannya (Fathonah, 2015).

Orang tua adalah ibu bapak yang dikenal mula pertama oleh putra putrinya. Dalam lingkungan keluarga orang tualah yang bertanggungjawab dalam suatu keluarga atau rumah tangga, dan sudah layaknya apabila orang tua mencurahkan perhatian dan bimbingan untuk mendidik anak agar supaya anak tersebut memperoleh dasar-dasar dan pola pergaulan hidup pendidikan yang baik dan benar, melalui penanaman disiplin dan kebebasan secara serasi (Padila, 2013).

Hasil penelitian pada umur responden dalam penelitian ini yang diklasifikasikan menurut Depkes RI (2009) sebagian besar berumur dewasa madya, yaitu umur 26-35 tahun sebanyak 16 orang (41\%). Penelitian ini sejalan dengan Fithriya (2014) bahwa usia yang paling memuaskan untuk membesarkan anak adalah antara 26 sampai 35 tahun. Selama waktu ini, orang tua dianggap berada pada kondisi kesehatan yang optimum. Orang tua yang berusia dewasa menunjukkan kepatuhan yang benar mengetahui tentang resiko penggunaan antibiotik sedangkan orang tua yang berusia dewasa awal mempengaruhi pengetahuan dalam penggunan obat pada anak.

Bertambahnya umur ibu akan berdampak pada pengalaman ibu dalam memberikan obat. Selain bertambah matang psikologis ibu dan dengan bertambahnya umur ibu dalam merawat anak, maka ibu memiliki pengalaman - pengalaman dalam pemberian obat oral cair pada anak dan dapat menilai manfaat dalam pemberian obat oral cair yang sebelumnya diberikan pada anak.

Tingkat pendidikan orang tua di Ruang Kanak - Kanak RSUD Jayapura didominasi berpendidikan SMA sebanyak 28 orang $(71,8 \%)$. Hal ini disebabkan sarana pendidikan di Kota Jayapua yang memadai. Pendidikan ibu akan berdampak pada daya pikir ibu dalam memahami masalah dalam memberikan obat oral cair pada anak melalui pentunjuk dalam kemasan obat maupun informasi yang diterima oleh apoteker maupun petugas kesehatan (perawat) yang bertugas di ruangan dalam memberiakn petunjuk penggunaan obat.

Hal ini juga diungkapkan oleh Prayoto (2014), bahwa pendidikan sangat mempengaruhi seseorang terhadap pengetahuan yang dimilikinya dimana melalui pendidikan, maka seseorang akan dapat mengembangkan potensi dirinya dan memperoleh pengetahuan maupun keterampilan-keterampilan yang dibutuhkannya untuk meningkatkan derajat kesehatannya. Semakin tinggi tingkat pendidikan seseorang maka semakin mudah mencerna semua informasi yang diperoleh segala keputusannya di dasari atas pemikiran yang rasional. 
Respoden yang diteliti sebagian besar tidak bekerja sebanyak 26 orang $(66,6 \%)$ disebabkan reponden adalah ibu rumah tangga dan mengandalkan suaminya dalam pemenuhan kebutuhan keluarga. Ibu yang tidak beklerja memliki lebih banyak waktu dalam menerima informasi yang disampaikan oleh apoteker maupun dalam melakukan perawatan pad aanknya yang sedang sakit, sehingga dengan perawatan yang dilakukananaknya menambah pengetahuan ibu dalam pemberian obat termasuk dengan pemberian obat oral cair pada anak. Hal ini juga diungkapkan oleh responden bahwa sebanyak 38 orang $(97,4 \%)$ memiliki pengalaman dalam memberikan obat cair oral pada anak. Dengan pengalaman tersebut diharapakan orang tua dalam memberikan obat cair oral pada anak dapat dilakukan dengan benar.

Informasi juga merupakan hal penting dalam pemberian obat cair oral pada anak. Adapun pernyataan reponden di Ruang Kanak - kanak tentang pengalamannya dalam memberikan obat cair orang sebanyak 33 orang $(84,6 \%)$. Sumber informasi yang dinyatakan oleh responden sebagian besar berasal dari apoteker dan petugas yang berjaga di ruangan.

Selama masa rawat inap, pengobatan langsung dalam pengawasan perawat yang memahami prosedur pemberian obat-obatan dengan resep dokter, namun pemberiannya dapat diberikan oleh keluarga pasien. Menurut Maria (2016) penyebab utama kesalahan dosis adalah karena kurangnya informasi dan tidak tersedianya alat ukur obat cair dan adanya kesalahan interpretasi yang berbeda pada pasien mengenai cara mengukur dengan alat takar.

\section{Pengetahuan tentang Pemberian Obat Oral Cair pada Anak}

Hasil penelitian diperoleh dari 39 responden pengetahuan responden tentang pemberian obat oral cair pada anak di Ruang Kanak - Kanak RSUD Jayapura dalam kategori pengetahuan baik sebanyak 21 orang $(53,8 \%)$, pengetahuan cukup sebanyak 13 orang $(33,4 \%)$ dan pengetahuan kurang sebanyak 5 orang $(12,8 \%)$. Hal ini menunjukkan bahwa pengetahuan orang tua tentang pemberian obat oral cair pada anak sebagian besar dengan kategori berpengetahuan baik.

Hal yang sama dari penelitian sebelumnya yang dilakukan oleh Maria (2016) di Rumah Sakit Khusus Anak 45 Yogyakarta dengan skor rata - rata pengetahuan $59,60 \%$ mengetahui dengan baik tentang pemberian obat cair oral pada anak.

Obat menguntungkan pasien dalam banyak hal, beberapa obat dapat menimbulkan efek samping yang serius atau berpotensi menimbulkan efek yang berbahaya bila tidak tepat diberikan (Potter \& Perry, 2012).

Hasil penelitian pengetahuan orang di Ruang Kanak-Kanak RSUD Jayapura dalam kategori pengetahuan baik, yaitu orang tua mengetahui bahwa semua jenis obat harus digunakan sampai habis $(100 \%)$, mengetahui cara penggunaan obat yang benar akan mempengaruhi kesembuhan penyakit $(97,4 \%)$, orang tua juga mengetahui bahwa penyimpanan obat oral cair harus di tempat yang sejuk dan terlindung cahaya matahari $(92,3 \%)$, cara minum obat oral cair tidak harus sesuai yang tertera pada etiket atau informasi dari apoteker di apotek $(79,5 \%)$ dan sebanyak $84,6 \%$ mengetahui kondisi obat oral cair rusak yaitu terjadi perubahan bentuk cairan, perubahan warna dan timbul bau pada obat oral cair serta sebanyak $89,7 \%$ mengetahui bahwa sebelum menggunakan obat oral cair dengan melihat anjuran yang tertera pada etiket/brosur dan sebanyak $87,2 \%$ orang tua mengetahui informasi cara penggunaan obat oral cair dengan bertanya kepada apoteker di apotek. Selain itu sebanyak $94 \%$ orang tua juga mengetahui bahwa penggunaan kembali obat oral cair orang lain yang memiliki gejala penyakit yang sama tidak dapat dilakukan.

Pengetahuan baik dari orang tua diasumsikan dari hasil kuesioner menunjukkan bahwa secara umum mengetahui tentang obat yang diberikan pada anak harus dihabiskan serta mengetahui cara pemberian obat oral cair pada anak dengan membaca pada label pada kemasan maupun menanyakan informasi dari apoteker serta kondisi obat yang masih dalam keadaan baik maupun sudah rusak yang dapat dilihat dari perubahan warna kemasan obat.

Menurut Kemenkes RI (2017), bahwa hal-hal yang harus diperhatikan dalam pemberian obat sediaan oral cair adalah memperhatikan kemasan/wadah harus tersegel dengan baik, tidak rusak, tidak berlubang, tanggal kadaluarsa jelas terbaca, cara minum, manfaat, efek samping dan kontraindinkasinya serta tanggal kadaluarsa obat.

Pengetahuan cukup pada orangtua tentang pemberian obat oral cair pada anak dengan jawaban benar yaitu sebanyak $69 \%$ 
orang tua mengetahui tidak boleh menggunakan sendok makan/sendok teh di rumah, $62 \%$ orang mengetahui bahwa obat tidak dapat digunakan jika rasa warna, bau, dan kejernihan dari larutan obat sudah berubah. Selain itu sebanyak $64 \%$ orang tua menanggapi bahwa dalam penggunaan obat oral cair perlu dilengkapi dengan sendok takar mempunyai tanda garis sesuai dengan ukuran dan $72 \%$ orang tua mengetahui bahwa penggunaan obat oral cair segera dihentikan apabila terjadi efek samping yang merugikan. Dalam pemberian obat, orang tua mengetahui bahwa sebelum obat oral cair diminumkan pada anak sebaiknya dikocok terlebih dahulu sebanyak $62 \%$ dan sebanyak $67 \%$ harus sesuai dengan waktu minum obat yang dianjurkan dimana sebanyak $64 \%$ mengetahui adanya efek samping yang merugikan bagi kesehatan bila pemberian tidak tepat serta $67 \%$ mengetahui cara penyimpanan obat oral cair dengan melihat cara penyimpanan pada kemasan obat dan $67 \%$ mengetahui bahwa cara penggunaan obat oral cair harus sesuai dengan anjuran yang tertera pada etiket atau brosur, informasi cara penggunaan obat oral cair yang lengkap dapat diperoleh dari apoteker di apotek serta. Selain itu dalam penggunaan sendok takar orang tua mengetahui bahwa penggunaan obat oral cair pada sendok takar dan sendok teh yang tersedia tidak sama dan setiap penggunaan kembali obat oral cair lain tidak dapat diberikan sebelum bertanya pada apoteker.

Pengetahuan kurang pada orang tua dari jawaban kuesioner tidak mengetahui yang menyatakan bahwa penggunaan obat oral cair dapat menggunakan sendok makan/sendok teh sebanyak 46\%. Sediaan cair memiliki keunggulan dalam hal kemudahan pemberian obat dan dosis yang diberikan relatif lebih akurat dan pengaturan dosis lebih mudah di variasi dengan penggunaan sendok takar (Paramita, 2017). Namun menurut Intiyani (2015) masih dijumpai penggunaan sediaan sirup menggunakan sendok yang ada di dapur bahkan menggunakan tutup botol kemasan obat. Pengertian sendok takar obat yang sebenarnya adalah berisi $5 \mathrm{ml}$. Gunakan sendok takar atau alat lain (pipet, gelas takar obat) jika minum obat dalam bentuk larutan/cair, jangan menggunakan sendok rumah tangga, karena ukuran sendok rumah tangga tidak sesuai untuk ukuran dosis (Intiyani, 2015).

Menurut Taufik (2011), pengetahuan merupakan hasil dari tahu dan ini terjadi setelah seseorang melakukan penginderaan terhadap suatu obyek tertentu. Pengetahuan merupakan domain yang sangat penting untuk terbentuknya perilaku seseorang.

Pengetahuan orang tua yang sebagian besar dilakukan baik di Ruang Anak-Anak RSUD Jayapura dalam pemberian obat oral cair pada anak ditinjau dari karakteristik orang tua dari 39 oang, sebanyak 38 orang $(97,4 \%)$ memiliki pengalaman dalam memberikan obat cair oral pada anak sedangkan 1 orang $(2,6 \%)$ tidak memiliki pengalaman. Sedangkan pengetahuan orang tua yang cukup disebabkan tidak semua orang tua mendapatkan informasi dalam pemberian obat cair oral pada anak sebanyak $15,4 \%$. Hal ini berdampak pada pengetahuan orang tua, dimana sebanyak 5 orang orang tua yang tidak ada pengalaman maupun informasi tentang obat cair oral pada anak memiliki pengetahuan kurang sebanyak 5 orang $(12,8 \%)$.

Pengetahuan ini dapat diperoleh dari pengalaman sendiri maupun dari orang lain. Fakta-fakta yang didapat dikumpulkan dan dipahami sebagai teori yang kemudian digunakan sebagai jawaban dari berbagai jenis fenomena kehidupan. Pengetahuan juga dapat diperoleh dengan cara tradisional (non-ilmiah) ataupun dengan cara ilmiah (modern) yang dilakukan dengan penelitian (Notoatmodjo, 2011).

Secara umum pengetahuan yang kurang pada orang tua di Ruang Anak-Anak RSUD Jayapura sebagian besar terletak pada penggunaan sendok takar. Hal ini akan berdampak pada kesalahan dosis atau kelebihan dosis yang mungkin dapat membahayakan pasien. Penyebab utama kesalahan dosis adalah karena tidak tersedianya alat ukur obat cair dan adanya kesalahan interpretasi yang berbeda pada pasien mengenai cara mengukur dengan alat takar. Dua kesalahan tersebut menyebabkan masyarakat cenderung menggunakan sendok makan/sendok teh yang terdapat di rumah untuk mengukur volume sediaan cair jika tidak ada sendok takar yang tersedia dalam obat cair (Maria, 2016).

Kesalahan tersebut dapat mengakibatkan terjadinya ketidakakuratan dosis. Penggunaan obat yang tidak sesuai dengan aturan, termasuk dosis konsumsi sediaan obat cair merupakan salah satu ketidakrasionalan penggunaan obat. Kesalahan pengambilan alat bantu seperti sendok takar dalam kemasan sediaan cair oral disebabkan kurangnya pengetahuan mengenai 
pentingnya ketepatan konsumsi obat sediaan cair oral mengggunakan sendok takar dan kurangnya pengetahuan orang mengenai dampak buruk kesalahan dalam menggunakan sendok takar sediaan cair oral

\section{SIMPULAN}

Berdasarkan hasil pembahasan, maka dapat disimpulkan bahwa pengetahuan orang tua tentang pemberian obat oral cair pada anak di Ruang Kanak - Kanak RSUD Jayapura dalam kategori pengetahuan baik sebanyak 21 orang $(53,8 \%)$, pengetahuan cukup sebanyak 13 orang $(33,4 \%)$ dan pengetahuan kurang sebanyak 5 orang $(12,8 \%)$.

\section{SARAN}

\section{Bagi Masyarakat}

Pengunaan obat pada keluarga, anak maupun individu disarankan untuk memperhatikan kemasan dan cara pemberian obat benar dan tepat agar obat yang diberikan efektif dan tidak terjadi toksisitas pada anak.

\section{Bagi Rumah Sakit}

Memberikan informasi pada pendamping pasien anak yang memberikan obat, karena pemahaman orang tua atau pendamping anak yang sakit berbeda pengetahuannya tentang pemberian obat cair oral anak dalam mencegah kesalahan pemberian dosis obat terutama melalui sendok takar.

\section{Bagi Orang Tua}

Mencari informasi dalam pemberian obat kepada anaknya melalui bacaan yang ada pada kemasan/label serta mencari informasi bila tidak mengetahuai pemberian obat pada pada apoteker mengenai cara pemberian obat yang benar pada anak.

\section{Bagi Peneliti Lanjutan}

Menambah variabel dengan melakukan observasi serta metode penelitian yang bebeda terkait dengan pemberian obat oral cair pada anak.

\section{DAFTAR PUSTAKA}

Andarmoyo (2012). Asuhan Keperawatan Keluarga. Jakarta, TIM.

Arikunto S (2010). Prosedur dan Pendekatan Penelitian. Rineka Cipta, Jakarta.

Athanasakis E (2012). The Method of Checking Medications Prior To
Administration: An Evidence Review. International Journal of Caring Sciences. www.international journalofcaringsciences.org.

Depkes RI (2010). Profil Kesehatan Indonesia. Depkes RI, Jakarta.

Direktorat Jenderal Pengawasan Obat dan Makanan RI (2014). Petunjuk Klinis Pengobatan. Direktorat Jenderal Pengawasan Obat dan Makanan. Kemenkes RI, Jakarta.

Direktorat Bina Farmasi Komunitas dan Klinik (2015). Farmasi dan Alat Kesehatan. Ditjen Bina Kefarmasian dan Alat Kesehatan Kementerian Kesehatan RI, Jakarta.

Fithriya S (2014). Hubungan Karakteristik Orang Tua Dengan Pengetahuan Dalam Pemberian Obat Antibiotik Pada Anak di Dusun Sonotengah Kabupaten Malang. Program Studi Ilmu Keperawatan Fakultas Kedokteran dan Ilmu Keperawatan. Universitas Islam Negeri Syarif Hidayatullah Jakarta.

Harmoko (2012). Asuhan Keperawatan Keluarga. Yogyakarta: Pustaka Pelajar.

Intiyani R (2015). Stop Gunakan Sendok Dapur. Tribun Jogja. http://www. tribunjogja.com. diakses 23 Mei 2019.

Kemenkes RI, 2015. Tanggung Jawab Apoteker Terhadap Keselamatan Pasien (Patient Safety). Direktorat Bina Farmasi Komunitas dan Klinik Ditjen Bina Kefarmasian dan Alat Kesehatan.

Kemenkes RI (2017). Pedoman Penggunaan Obat Bebas dan Bebas Terbatas. Direktorat Bina Farmasi Komunitas dan Klinik Ditjen Bina Kefarmasian dan Alat Kesehatan.

Kemenkes RI (2018). Riset Kesehatan Dasar Nasional 2018. Kemenkes RI, Jakarta. Jakarta.

Kozier, B. Erb, G. \& Blais, K (2011). Konsep dan Perspektif Tindakan Keperawatan Profesional Professional. Jakarta: EGC.

Kuntarti (2015). Tingkat Penerapan Prinsip Enam Tepat dalam pemberian obat oleh Perawat. FKUI, Jakarta.

Mangkunegara A.P (2011). Evaluasi Kinerja SDM. Refika Aditama. Jakarta.

Maria M (2016). Pengetahuan Penggunaan Obat Sediaan Oral cair Pada Pendamping Pasien Anak Tahun 2015 (Studi Kasus Rumah Sakit Khusus Anak 45 Yogyakarta) Skripsi. Fakultas Farmasi Universitas Sanata Dharma Yogyakarta. 
Maryam S (2014). Promosi Kesehatan. Jakarta: EGC.

Mubarak W (2011). Promosi Kesehatan. TIM, Jakarta.

Murini T (2017). Bentuk sediaan obat (BSO) dalam preskripsi. Bioavailabilitas obat \& pemilihan BSO dalam preskripsi. http:///www.ugm.ac.id. diakses 23 Mei 2019.

Notoatmodjo S (2011). Ilmu Kesehatan Masyarakat, Perilaku dan Seni. Rineka Cipta, Jakarta.

Notoatmodjo S (2012). Metode Penelitian Kesehatan. Rineka Cipta, Jakarta.

Nursalam (2010). Dasar - Dasar Riset Keperawatan. Jkarta: EGC.

Padila (2013). Buku Ajar Keperawatan Keluarag. Dilengkapi Aplikasi Kasus Askep Keluarga Terapi Herbal dan Terapi Modalitas. Yogyakarta: Nuha Medika.

Panagakou, Sotiria G (2012). Risk Factors of Antibiotic Misuse for Upper Respiratory Tract Infection in Children : Result from a Cross-Sectional Knowledge-Attitude-Practice Study in Greece. International Scholarly Research Network Volume 2012, Article ID 685302,8 pages.

Peraturan Menteri Kesehatan Republik Indonesia Nomor 2500/ Menkes/SK/XII/2011, Tentang pemberian obat untuk anak.

Potter dan Perry (2012). Buku Ajar Fundamental Keperawatan: Konsep, Proses dan Praktik. Vol 4. Jakarta: EGC.

Paramita HE (2017). Sediaan Liquid Larutan Makalah. Program Studi S1 Farmasi
Stikes Rumah Sakit Anwar Medika Sidoarjo.

Prasetyawati (2012). Ilmu Kesehatan Masyarakat Untuk Kebidanan Holistik. Jakarta: Nuha Medika.

Prayoto (2014). Teori, Sikap \& Perilaku dalam Kesehatan dilengkapi contoh kuesioner. Nuha Medika, Yogyakarta.

Putra, S (2012). Buku Pintar Apoteker. Jogjakarta.

Quizhpe., Arturo (2013). Differences in Antibiotic use and Knowledge between adolescent and adult mothers in Ecuador. F1000Research, 2: 108.

Sugiyono (2013). Metode Penelitian Manajemen. Bandung: Alfabeta.

Sunaryo (2015). Sosiologi Keperawatan. Pendekatan dan Aplikasi untuk Keperawatan. Refika Aditama, Jakarta.

Swarjana, 2013. Metode Penelitian Kesehatan. Jakarta: Bina Rupa Aksara.

Taufik (2010). Asal - Usul Pengetahuan. http://www.ipb.ac.id. diakses 20 Agustus 2018.

Tambayong (2013). Farmakologi Untuk Keperawatan. Widiya Medika, Jakarta.

Undang-Undang No.20 tahun 2003 tentang Sistem Pendidikan Nasional.

Undang-Undang No.36 tahun 2009 tentang Kesehatan.

Wahyuni RM (2015). Perilaku Perawat Menerapkan Prinsip Enam Benar Pemberian Obat Mencegah Kejadian Tidak Diharapkan. Journals of Ners Community Volume 6 No 1 Juni 2015.

World Health Organization (WHO), 2017. Swamedication of drugs. http://www.who.int.com. diakses 20 Februari 2019. 